\title{
The Expression and Localization of Synaptic Vesicle Antigens at Neuromuscular Junctions In Vitro'
}

\author{
JOHN L. BIXBY ${ }^{2}$ AND LOUIS F. REICHARDT \\ Division of Neurobiology, Department of Physiology, School of Medicine, University of California, San Francisco, \\ San Francisco, California 94143
}

\begin{abstract}
To examine the biochemical differentiation of presynaptic nerve terminals in vitro, we studied the expression and localization at synapses of two synaptic vesicle-specific antigens, synapsin I and protein p65. We purified these proteins from brain and raised a rabbit antiserum against each of them. Chick synapsin I had a slightly smaller molecular weight than its mammalian homologue, although the two share several properties. With the anti-p65 serum, the protein p65 could be detected consistently in presynaptic terminals at the neuromuscular junction in vivo, as had been previously shown for synapsin I. These antisera proved sufficiently sensitive to allow a study of the developmental expression of the antigens in embryonic chick brain, using protein blots. The two antigens are not coordinately regulated; protein p65 was detected substantially sooner in development that was synapsin I.
\end{abstract}

Both synapsin I and protein p65 are expressed by ciliary ganglion neurons in vitro, as assessed by immunofluorescence using the affinity-purified antisera. The two antigens co-localized at all times in culture. Neurons grown alone were reliably stained only after 4 to 5 days in culture, but comparable levels of staining were found after 1 day when neurons were co-cultured with embryonic myotubes. In the co-cultures, staining was initially high in growth cones and neurites, but the brightest staining became confined to sites of nervemuscle contact over $\mathbf{4}$ to 5 days in culture. In mature cultures, patches of bright staining for the vesicle antigens coincided with patches of acetylcholine receptors, suggesting that the antigens had become localized at synapses. The time course of this localization process suggests that it corresponds to the morphological maturation of synapses. It should be possible to exploit this system to obtain information about the molecules and processes involved in the induction of presynaptic differentiation.

Received February 25, 1985; Revised April 18, 1985;

Accepted April 22, 1985

\footnotetext{
${ }^{1}$ We thank D. Milfay and A. Gordon for a gift of $\gamma-\left[{ }^{32} \mathrm{P}\right] A$ ATP, H. Bourne for a gift of purified catalytic subunit of cAMP-dependent protein kinase, $J$ Browning for a gift of rhodamine-conjugated $\alpha$-bungarotoxin, M. Browning and $P$. Greengard for providing the hybridoma cell line secreting monoclonal antibody 10B1, Anne Calof for providing purified ovotransferrin, D. Berg and $D$. Pellegrini for showing us the ciliary ganglion preparation, and $\mathrm{K}$. Tomaselli, D. Clegg, and especially $Z$. Hall for thoughtful and incisive criticisms of early drafts of this manuscript. This work was supported by Program Grant, NS16033 from the National Institutes of Health and a grant from the Muscular Dystrophy Association to L. F. R. J. L. B. was a fellow of the Muscular Dystrophy Association.
}

${ }^{2}$ To whom correspondence should be addressed.
The processes governing the formation and maintenance of synapses during development are still poorly understood. For the case of the vertebrate neuromuscular junction, the best studied synapse in the nervous system, much is known concerning the physiological and morphological changes that accompany development, both in vivo and in culturc. Comparativcly littlo is known, however, about the molecular events that underlie these changes, particularly in the presynaptic terminal. The investigations described in this paper characterize some of the biochemical changes occurring in developing nerve terminals that are useful for studying synaptic development

The majority of biochemical studies on neuromuscular development in vitro have concentrated on postsynaptic events; in particular the observation that functional synapses in vivo and in vitro are associated with clusters of acetylcholine receptors (AChRs; e.g. Cohen and Fischbach, 1977) has focused attention on the regulation of the synthesis, redistribution, and stabilization of these receptors on the surface of myotubes (reviewed in Fambrough, 1979). More recently, a variety of other molecules have been found to be concentrated at synaptic sites in myotubes (Hall et al., 1981; Burden 1982; Burden et al., 1983; Bloch and Hall, 1983). It seems likely that some of the information obtained about the control of receptor synthesis and localization will be useful for understanding the regulation of postsynaptic differentiation in general. It is obviously of interest to obtain similar information about the regulation of expression of molecules concentrated in the presynaptic terminal.

In recent years immunological techniques have been used to define a number of molecules that are specifically localized in presynaptic nerve terminals, in both the central and peripheral nervous systems of mature animals. The majority of molecules that have been identified are associated with synaptic vesicles. These include the phosphoprotein synapsin I (DeCamilli et al., 1983a), a 65-kilodalton (kd) membrane protein (Matthew et al., 1981), and several distincl molecules first discovered in synaptic vesicles isolated from Torpedo electric organ (Carlson and Kelly, 1983; Buckley and Kelly, 1985).

Synapsin 1 is a nervous system-specific protein, purified from mammalian brain, which is bound to the cytoplasmic surface of synaptic vesicles at many and possibly all synapses (DeCamilli et al., 1983b). Greengard and co-workers (Huttner et al., 1983) have shown that synapsin I is a major protein in purified synaptic vesicle preparations. A few studies have examined the development of expression of this protein and its correlation with synapse formation. Its levels increase in late fetal and early postnatal rat and guinea pig brain at approximately the same time as synaptic density is increasing (Lohmann et al., 1978). More recently, it has been shown with immunocytochemistry to appear in the Purkinjie cell layer of chick and monkey cerebellum around the time of initial appearance of synapses (DeCamilli et al., 1983a; Levitt et al., 1984).

The protein p65 is a synaptic vesicle protein $\left(M_{\mathrm{r}}=\sim 65,000\right)$ 
which was initially identified by two monoclonal antibodies raised to rat synaptic membranes. It has a wide distribution among vertebrate species, is highly enriched in synaptic vesicle preparations (Huttner et al., 1983), and appears to be associated with vesicles in most and possibly all neurons (Matthew et al., 1981). Although the molecule is not well characterized, evidence suggests that it is an integral membrane protein. In the only developmental study of this protein, it was reported that levels of protein p65 increase significantly during the second postnatal week in rat sympathetic ganglia, shortly after the major period of synapse formation (Greif and Reichardt, 1982). No major changes in the distribution of p65 antigen during development were reported.

The aim of our experiments is to develop a system in which these two proteins can be used as markers for synaptic development. We have chosen to work with chicks because of the ease with which embryos can be obtained and studied, and because of the existence in chicks of a well characterized population of cholinergic neurons, the ciliary ganglion neurons. When cultured at a time just before they normally form synapses (Landmesser and Pilar, 1974), ciliary neurons innervate muscle in vitro (Betz, 1976). Our experiments describe the distribution of protein p65 and synapsin I during the maturation in vitro of the neuromuscular junctions formed by chick ciliary ganglion neurons and embryonic chick myotubes. Because the available antibodics to the mammalian synaptic antigens proved unsatisfactory reagents for our studies, we purified the two proteins and made a rabbit antiserum to each of them. We demonstrate here that these antisera are sensitive and specific reagents that can be used to follow nerve terminal antigens both in vivo and in culture.

\section{Materials and Methods}

Animals. Fertile White Leghorn chicken eggs at various ages were obtained from Feather Hill Farm (Petaluma, CA) and kept in an incubator at $38^{\circ} \mathrm{C}$ and $95 \%$ humidity until use. Fresh bovine brains and adult chicken heads were obtained from local slaughterhouses.

Materials. Laminin was purified from the Engelbreth-Holm-Swarm sarcoma (Kleinman et al., 1982). Aquacide was obtained from Calbiochem (La Jolla, CA). $\left.\gamma-{ }^{32} P\right] A T P$ was a gift of $D$. Milfay. The catalytic subunit of bovine CAMPdependent protein kinase was kindly provided by Dr. H. Bourne. Ascites fluid containing monoclonal antibody 10B1 was prepared from a hybridoma that was isolated and generously provided by Drs. M. Browning and P. Greengard. Nitrocellulose paper was from Schleicher and Schuell (Keene, NH). All other chemicals were purchased from Sigma Chemical Co. (St. Louis, MO).

Preparation of brain membranes. All steps were performed at 0 to $4^{\circ} \mathrm{C}$ Brains were homogenized in a Teflon-glass homogenizer or a Waring blender with 4 vol of buffer A (25 mM HEPES, pH 7.2, $0.32 \mathrm{M}$ sucrose, $2 \mathrm{~mm}$ EDTA, $0.1 \mu \mathrm{M}$ pepstatin, $2 \mathrm{~mm} N$-ethylmaleimide, with $100 \mu \mathrm{M}$ phenylmethylsulfonyl fluoride added just before homogenization). After four additional volumes of buffer $A$ were mixed in with the homogenate, the mixture was centrifuged at $800 \times g$ for $10 \mathrm{~min}$ in a Sorvall RC5B centrifuge. The resulting supernatant was centrifuged at $12,000 \times g$ for $25 \mathrm{~min}$. After the pellet was resuspended in buffer $A$, the mixture was centrifuged again $(12,000 \times \mathrm{g}, 25 \mathrm{~min})$. The final pellet was resuspended in buffer $A$ without sucrose. This yielded a crude membrane fraction (lysed P2), which was used for further purification steps or frozen in a $\mathrm{CO}_{2} /$ ethanol bath and stored at $-80^{\circ} \mathrm{C}$.

Preparation of chick synapsin I. Synapsin I was purified from adult chicken brains by a modification of the procedure developed by Ueda and Greengard (1977) for purification of mammalian synapsin I. A lysed P2 fraction was prepared from $690 \mathrm{gm}$ of chicken brain as described above, and synapsin I was partially purified from this fraction using steps 2 to 5 of the procedures described by Ueda and Greengard (1977). As an additional step for material to be used as immunogen, this preparation was dialyzed against $0.15 \mathrm{M}$ Tris$\mathrm{Cl}, \mathrm{pH} 7.0$, and fractionated on a column of Bio gel P $300(0.9 \mathrm{~cm} \times 30 \mathrm{~cm})$, using the same buffer as an eluant. One-milliliter fractions were collected and assayed for synapsin I on protein blots. Synapsin I (immunoreactive with antibovine syriapsin I anliserumil) eluled as a sirlgle peak just after the void volume on this column. All steps were performed at $4^{\circ} \mathrm{C}$. Bovine synapsin I was purified from bovine cerebral cortex by the same method, omitting the tinal P-300 column.

Purification of bovine p65. A lysed P2 fraction was prepared from 310 gm of bovine cerebral cortex as described above. The p65 protein was solubilized by addition of an equal volume of $2 x$ extraction buffer $(75 \mathrm{~mm}$ $\mathrm{NaPO}_{4}, \mathrm{pH} 7.4,0.4 \mathrm{M} \mathrm{NaCl}, 1 \%$ 3-[(3-cholamidopropyl)dimethylammonio]-1 propanesulfonate (CHAPS) and stirring for 1 to $4 \mathrm{hr}$ at $4^{\circ} \mathrm{C}$. After the extract was centrifuged at $16,000 \times g$ for $20 \mathrm{~min}$, the supernatant, containing $\sim 3 \mathrm{mg}$ of protein/ $\mathrm{ml}$, was passed three times through an antibody 48 Sepharose affinity column $(1 \mathrm{~cm} \times 8 \mathrm{~cm})$ at a flow rate of $1 \mathrm{ml} / \mathrm{min}$. After the column was washed with 5 to 10 vol of $0.3 \mathrm{M} \mathrm{NaCl}, 0.5 \%$ CHAPS, 50 $\mathrm{mM} \mathrm{PO}_{4}, \mathrm{pH} 7.2$, the p65 protein was eluted with either $0.3 \%$ CHAPS, $0.1 \mathrm{M}$ glycine, $\mathrm{pH} 2.2$, or with $3 \mathrm{M} \mathrm{NaSCN}, 0.3 \%$ CHAPS, $50 \mathrm{~mm} \mathrm{NaPO}_{4}, \mathrm{pH} 7.2$. In the former case, $1 \cdot \mathrm{ml}$ fractions were neutralized by collection into $0.2 \mathrm{ml}$ of $0.5 \mathrm{M}$ Tris base. Pooled fractions containing protein were dialyzed against $0.2 \%$ CHAPS, $25 \mathrm{~mm} \mathrm{Na}$ HEPES, pH 7.2, and were either lyophilized or concentrated by dialysis against polyethylene glycol (Aquacide).

Preparation of Sepharose affinity columns. Affinity columns (protein p65. antibody 48, and bovine synapsin I) were prepared using Affi-gel 10 (BioRad Laboratories, Richmond, CA). The gel was washed with 2 vol of isopropanol three times and then with cold distilled $\mathrm{H}_{2} \mathrm{O}$ three times. Proteins were added in $0.1 \mathrm{M} \mathrm{Na}$-HEPES buffer $(\mathrm{pH} 7.0$, antibody 48 and $\mathrm{p} 65 ; \mathrm{pH}$ 7.6. bovine synapsin l) at concentrations of 0.5 to $3 \mathrm{mg}$ of protein/ $\mathrm{ml}$ of gel, and the mixture was rocked at $4^{\circ} \mathrm{C}$ for 2 to $4 \mathrm{hr}$. Unbound protein was eluted with $0.5 \mathrm{M} \mathrm{NaCl}$ in $50 \mathrm{~mm}$ HEPES buffer, $\mathrm{pH} 7.0$, and the total protein in the supernatant was determined. Coupling efficiencies were between 70 and $95 \%$.

The antibody $48 \mathrm{lgG}$ was purified from ascites fluid by a 0 to $100 \mathrm{~mm}$ $\mathrm{NaCl}$ gradient in $20 \mathrm{~mm}$ Tris, $\mathrm{pH} 7.2$, on a column of DEAE-Affi-gel Blue (Bruck et al., 1982).

Preparalion of crude-cAMP-dependent protein kinase. Protein kinase was solubilized and purified through step 3 of Uno et al (1977).

In vitro phosphorylation. We carried out cAMP-dependent phosphorylation in vitro, using a modification of the procedure of Forn and Greengard (1978). Briefly, phosphorylation was initiated by the addition of $10 \mu l$ of $\gamma \cdot{ }^{32}$ P]ATP (specific activity, $500 \mu \mathrm{Ci} / \mathrm{ml}$ ) to a $90-\mu$ l mixture containing $50 \mathrm{~mm}$ Na-HEPES, $\mathrm{pH} 7.4,10 \mathrm{~mm} \mathrm{MgCl}_{2}, 10 \mu \mathrm{M}$ cAMP, 20 units of crude protein kinase, and 5 $\mu$ l of either bovine P2 $(5 \mathrm{mg} / \mathrm{ml})$, chicken P2 $(20 \mathrm{mg} / \mathrm{ml})$, bovine synapsin 1 $(0.7 \mathrm{mg} / \mathrm{ml})$, or chicken synapsin I $(0.5 \mathrm{mg} / \mathrm{ml})$. In one experiment 30 units of purified catalytic subunit of CAMP-dependent protein kinase was substituted for the crude kinase. After 20 to 30 min incubation at $30^{\circ} \mathrm{C}$, the reaction was stopped by the addition of $25 \mu \mathrm{l}$ of a solution containing $10 \%$ SDS, $25 \%$ glycerol, $0.01 \%$ bromphenol blue, $0.25 \mathrm{M}$ Tris, $\mathrm{pH} 6.8$, and boiling for $5 \mathrm{~min}$. Aliquots of $25 \mu \mathrm{l}$ were immediately subjected to electrophoresis on SDS-polyacrylamide geis. The gels were stained with Coomassie blue, destained, and dried. Labeled proteins were identified by autoradiograph using Kodak X-Omat AR film and a DuPont Cronex intensifying screen.

Antigen blotting. Proteins were separated by SUS-polyacrylamide gel electrophoresis using the method of Laemmli (1970). Proteins were transferred to nitrocellulose sheets $(0.2-\mu \mathrm{m}$ pore) electrophoretically in a blotting apparatus (Bio-Rad), using a current of 0.4 to $0.7 \mathrm{~A}$ for $2 \mathrm{hr}$ (Towbin et al (1979). The nitrocellulose sheets were incubated in phosphate-buffered saline (PBS)-hemoglobin $\left(0.4 \%\right.$ hemoglobin, $\left.0.15 \mathrm{M} \mathrm{NaCl}, 10 \mathrm{mM} \mathrm{PO}_{4}, \mathrm{pH} 7.4\right)$ for $30 \mathrm{~min}$ at room temperature, and then with antibody diluted in PBS-hemoglobin for 12 to $16 \mathrm{hr}$ at $4^{\circ} \mathrm{C}$. The blots were washed with PBS two times for 5 min each and twice for $5 \mathrm{~min}$ with $0.1 \%$ Triton X-100 in PBS, and then were incubated with a 1:1000 dilution of peroxidase-labeled second antibody (goat anti-rabbit lgG or goat anti-mouse lgG; Cappell Laboratories, West Chester, $\mathrm{PA}$ ) for 6 to $8 \mathrm{hr}$ at room temperature. They were then washed again as before, with four changes of buffer. Sites of antibody binding were detected using $\mathrm{H}_{2} \mathrm{O}_{2}$ and chloronaphthol for 15 to $30 \mathrm{~min}$ at room temperature as described by Hawkes et al (1982).

Immunizations. Female New Zealand White rabbits were immunized with 100 to $150 \mu \mathrm{g}$ of antigen emulsified with complete Freund's adjuvant to which an additional $5 \mathrm{mg}$ of lyophilized tubercle bacilli (Difco Laboratories, Detroit, Ml) had been added. Fifteen days later, the rabbits were boosted with $100 \mu \mathrm{g}$ of antigen emulsified with incomplete Freund's adjuvant. The animals were bled at 5- to 7-day intervals and boosted (antigen in incomplete Freund's) at 16- to 30-day intervals. Antibody titers were monitored by an enzyme-linked immunosorbent assay using chicken brain membranes ad sorbed to a polyvinylchloride microtiter plate as the solid phase, and peroxidase-conjugated goat anti-rabbit IgG as the indirect probe (Engvall, 1980).

Protein determinations. Protein was determined by the amido black method (Schaffner and Weissmann, 1973)

Cell culture. Myotubes were prepared from pectoral muscle of 11-day chick embryos following the procedure of Cohen and Fischbach (1977) and were grown on collagen-coated glass coverslips. Ciliary ganglion neurons were dissociated from 8-day chick embryos and plated onto 4 to 5-day-old muscle cultures (Nishi and Berg, 1977). The culture medium was Eagle's minimal essential medium with Earle's balanced salt solution, $10 \%$ horse serum, $2 \mathrm{~mm}$ glutamine, $25 \mu \mathrm{g} / \mathrm{ml}$ of ovotransferrin (Calof and Reichardt, 1984), and 100 units $/ \mathrm{ml}$ of penicillin and streptomycin. In some experiments, neurons were plated directly onto coverslips coated with laminin $(10 \mu \mathrm{g} / \mathrm{ml})$. In these cases, the medium was supplemented with $3 \%$ embryo eye extract 
(Nishi and Berg, 1981), and the ovotransferrin was omitted. Cells were fed every other day.

Immunofluorescence. AChRs were labeled by incubation for $1 \mathrm{hr}$ at room temperature in medium containing a 1:1000 dilution of rhodamine-conjugated $\alpha$-bungarotoxin (peak IV of Ravdin and Axelrod, 1977; $4.1 \mu \mathrm{M}$; prepared by Dr. J. Browning). In control experiments, unlabeled bungarotoxin at $10^{-5} \mathrm{gm} /$ $\mathrm{ml}$ was included in the medium. In such cases, no surface rhodamine staining of the cultures was observed. The coverslips were then fixed for $10 \mathrm{~min}$ at room temperature in $10 \%$ formalin/PBS/5\% sucrose, washed five times in PBS, and incubated with first antibody. Antibodies were diluted to concentrations of 0.2 to $1.0 \mu \mathrm{g} / \mathrm{ml}$ in PBS with $1 \%$ goat serum, $0.05 \%$ saponin. After a 1-hr incubation at room temperature, the coverslips were washed five times in PBS and incubated with a 1:150 or 1:300 dilution of second antibody (affinity-purified fluorescein isothiocyanate-conjugated goat anti-rabbit lgG or rhodamine isothiocyanate-conjugated goat anti-mouse IgG, Cappell Laboratories) for $1 \mathrm{hr}$ at room temperature. The coverslips were then washed five times in PBS, rinsed in distilled $\mathrm{H}_{2} \mathrm{O}$, and mounted in Gelvatol. Stained cells were examined under Zeiss fluorescence optics with an oil immersion $\times 63$ (n.a. $=1.4$ ) phase lens, and photographed with Kodak Tri-X film. Control incubations were done with normal rabbit (mouse) immunoglobulin at a concentration of 1 to $3 \mu \mathrm{g} / \mathrm{ml}$ substituted for first antibody. No staining above background was observed on these coverslips.

Quantitation procedures. For quantitation of labeling patterns, two different search procedures were employed. In most cases, neurite-myotube contacts were located under phase contrast optics, and then fluorescein optics were used to judge whether vesicle antigen staining levels at the contact were above those seen in parts of the neurite not contacting muscle. Finally, rhodamine optics were used to look for a patch of AChRs at the contact. In some cases, the cultures were searched under fluorescein optics for clusters of vesicle antigens, and then rhodamine optics were used to see whether the cluster was associated with a receptor patch.

\section{Results}

Antiserum to chick synapsin I. Because intitial experiments with chicken brain membranes suggested that antibodies to bovine synapsin I have a low cross-reactivity with the chick homologue, we purified the protein from adult chicken brain and used this material to raise more reactive antibodies. Following a modification of the procedure developed for mammalian synapsin I (Ueda and Greengard, 1977), we obtained a fraction enriched for synapsin I consisting of a doublet of apparent $M_{r}=69,000$ and 76,000 , together with several minor contaminating bands (data not shown). This was estimated to be 80 to $90 \%$ pure by gel electrophoresis. The doublet reacted on blots with antibodies to bovine synapsin I (data not shown). This preparation was used to raise a rabbit antiserum, and the serum obtained was tested on protein blots of bovine and chicken brain membranes. As shown in Figure $1 A$, the antiserum recognized authentic mammalian synapsin I (a doublet at 80 and 84 $\mathrm{kd}$ on SDS gels), and five bands in chicken brain membranes, with a major band at $79 \mathrm{kd}$ (Fig. 1, B and C). Affinity purification of the antiserum on a column of bovine synapsin I yielded an antibody that recognized a single band (or a closely spaced doublet) of $M_{\mathrm{r}}=$ 79,000 on protein blots of chick brain membranes (Fig. 1D). The results in Figure 2 show that a monoclonal antibody to mammalian synapsin I, provided by Drs. M. Browning and P. Greengard, recognizes the same antigens as are recognized by the purified rabbit antibody in blots of bovine and chick brain membranes.

To test further whether the band seen at $79 \mathrm{kd}$ corresponds to synapsin I, we examined its reaction with a protein kinase. Mammalian synapsin I is a phosphoprotein that is a major substrate in brain for both cAMP-dependent and $\mathrm{Ca}^{2+} /$ calmodulin-dependent protein kinases (Huttner and Greengard, 1979; Walaas et al., 1983a, b). We incubated a cAMP-dependent kinase fraction in the presence or absence of cAMP, with $\left.\gamma-{ }^{32} \mathrm{P}\right] \mathrm{ATP}$ and either chick brain membranes, purified bovine synapsin I, or the partially purified chick homologue. The purified proteins (bovine and chick), as well as several proteins in the chick brain membranes, were phosphorylated by the kinase (Fig. 2, $E$ to $I$ ). Most of these correspond to phosphorylated substrates seen in mammalian brain (Walaas et al., 1983a). The only substrate for CAMP-dependent protein kinase present in chicken brain membranes with an apparent molecular weight near

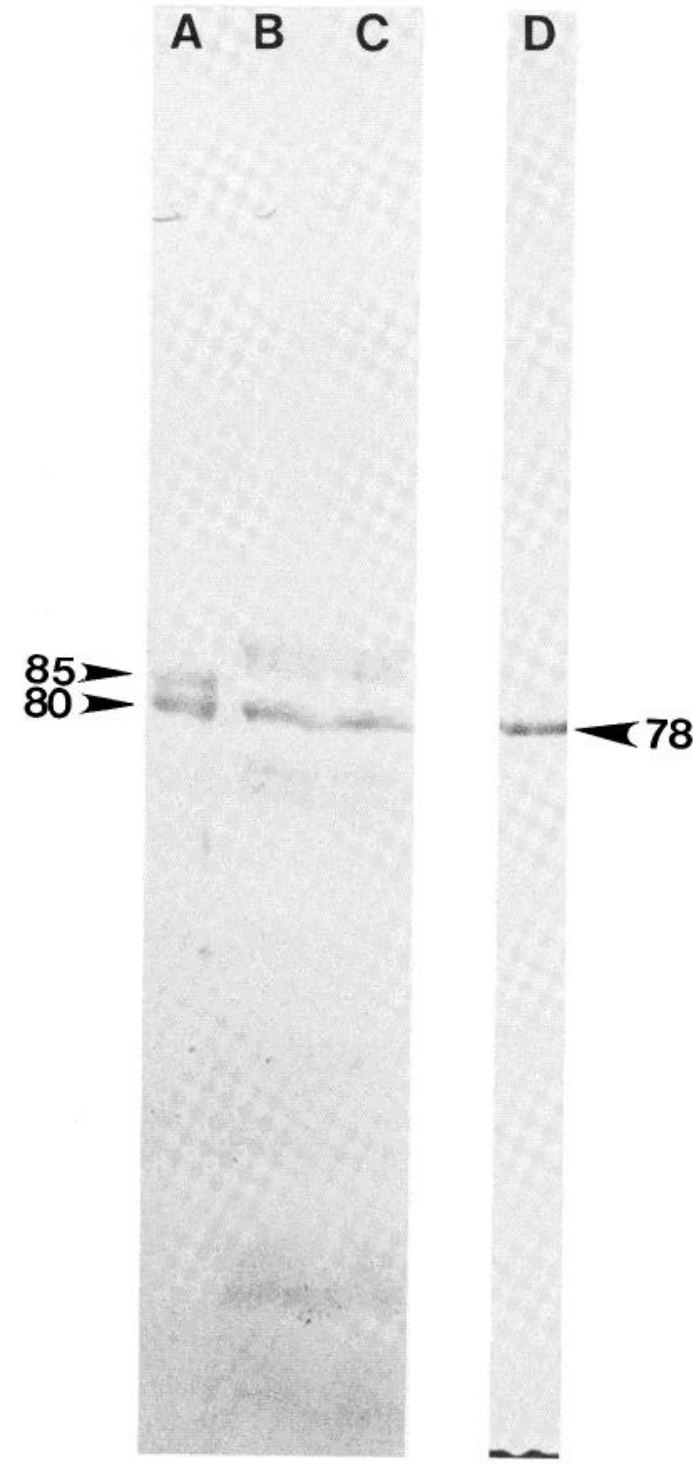

Figure 1. Protein blots of an antibody to chick synapsin I. Lanes $A$ to $C$ are from a single blot, and lane $D$ is from a second blot. Proteins were blotted from SDS gels onto nitrocellulose paper, and the blots were stained with either a crude rabbit antiserum to chicken synapsin I (1:400; $A$ to $C)$, or the same antibody affinity purified on bovine synapsin । $(0.3 \mu \mathrm{g} / \mathrm{ml} ; D)$. Numbers by arrowheads indicate calculated molecular weights $\left(\times 10^{3}\right)$. Lane $A, 0.6 \mu \mathrm{g}$ of bovine synapsin I; Lanes $B$ to $D, 150 \mu \mathrm{g}$ of chick brain membranes (P2).

that of mammalian synapsin I is a band of $M_{r}=79,000$, the same molecular weight as that of the proteins bound by antibodies to mammalian synapsin I. In summary, the evidence indicates that chicken synapsin I is a closely spaced doublet of $M_{\mathrm{r}}=78,000$ to 79,000 , which is a substrate for cAMP-dependent protein kinase.

The chick brain membranes showed no evidence of immunoreactive bands at 76 or $69 \mathrm{kd}$, which were the major components in the original preparation to which the antiserum was made (Fig. 2, B and $D)$. Because both the 76- and 69-kd bands in this preparation reacted on blots with polyclonal antisera against mammalian synapsin I (not shown) and were specifically phosphorylated by cAMP. dependent protein kinase (Fig. 2, E and F), we assume that these two bands are a degraded form of the native protein.

Antiserum to bovine p65. Matthew et al. (1981) reported the generation of two monoclonal antibodies 30 and 48), which recognize a synaptic vesicle-associated protein of apparent $M_{\mathrm{r}}=65,000$ 


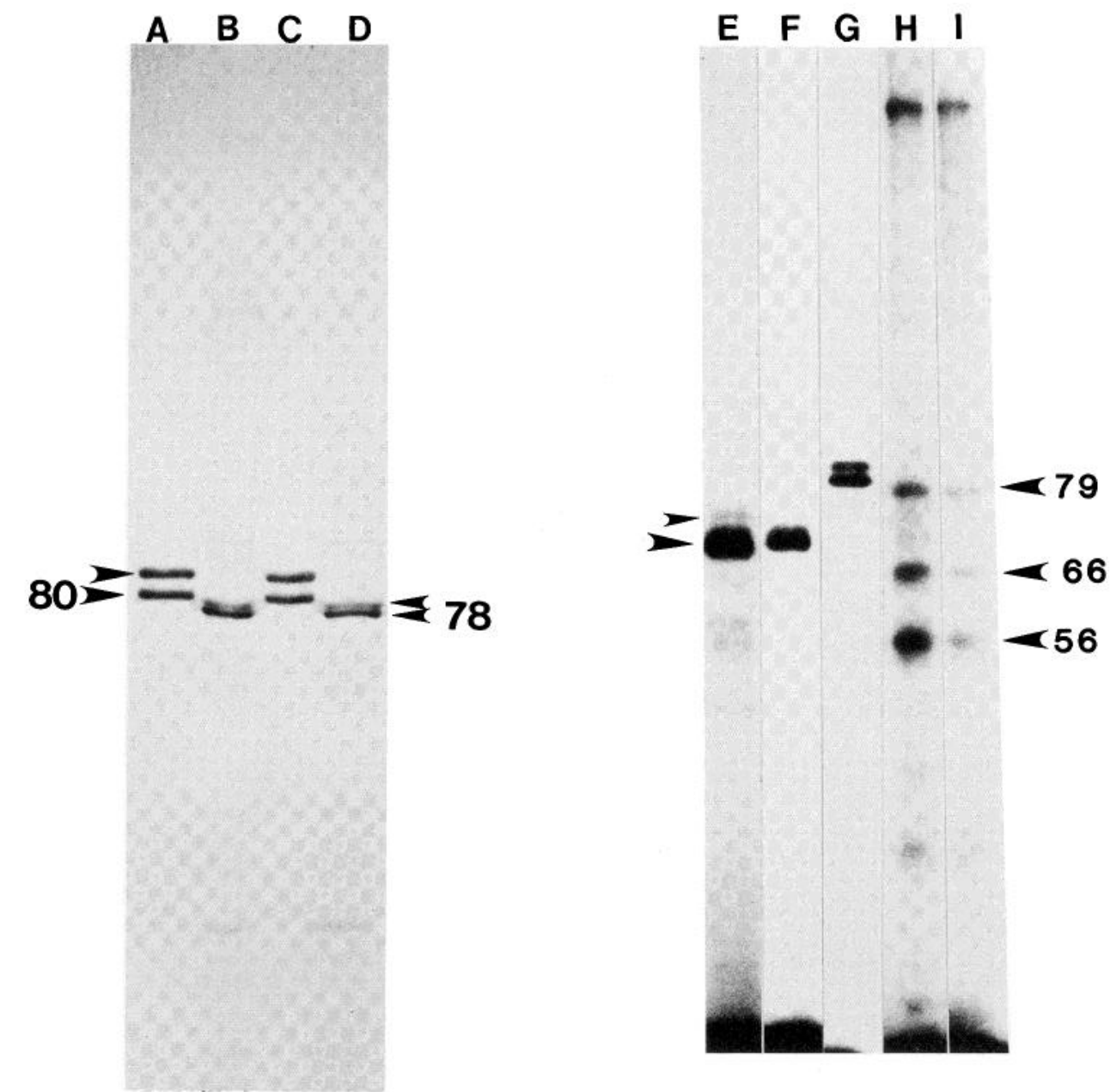

Figure 2. Characterization of chick synapsin I. Lanes $A$ to $D$ are from a protein blot using a monoclonal antibody to mammalian synapsin I (ascites fluid diluted 1:300). The positions of the mammalian synapsin I doublet at $80 \mathrm{kd}$ and the chick synapsin I doublet at $78 \mathrm{kd}$ are indicated by arrowheads. Lanes $A$ and C. $120 \mu \mathrm{g}$ of bovine brain membranes (P2); lanes $B$ and $D, 150 \mu \mathrm{g}$ of chick P2. Lanes $E$ to / are autoradiographs of proteins labeled in vitro with [ $\left.{ }^{32} P\right] A T P$. Lanes $E$ and $F$ contain purified chick synapsin I (lane $E$ is an overexposure to show the upper band), lane $G$ contains purified bovine synapsin I, and lanes $H$ and I contain chick P2. Lanes E to $H$ are from proteins incubated with the catalytic subunit of cAMP-dependent protein kinase, and lane $I$ is from proteins incubated with no added kinase. The phosphorylation evident in lane $I$ is probably due to the presence of some kinase in the chick P2. Lanes $H$ and / are simultaneous exposures of the same amount of protein and thus can be directly compared. Arrowheads to the left of lane $E$ indicate the position of the purified chick synapsin I doublet. Numbers by arrowheads on the right indicate calculated molecular weights $\left(\times 10^{3}\right)$.

(p65). The antibodies detect this antigen in nearly every location in which there are synaptic vesicles, but it could not consistently be found at the neuromuscular junction. To obtain a more sensitive antibody preparation for $p 65$, we raised a polyclonal antiserum using the protein solubilized from bovine brain membranes and purified on an affinity column of antibody 48 . This simple procedure yielded essentially homogeneous material, with only one or two minor contaminating bands on a silver-stained gel (Fig. $3 A$ ). The band at 40 $\mathrm{kd}$ is probably a degradation product of p65, since it reacts with antibody 48 on Western blots (data not shown). A rabbit antiserum to the affinity-purified p65 recognized a major band at $65 \mathrm{kd}$ in chicken brain, as well as a few fainter bands (Fig. 3D). After affinity purification of the antiserum on a column of p65, it recognized a single band at $65 \mathrm{kd}$ on protein blots of chicken brain (Fig. 3F). With the affinity-purified antibody, it was possible to demonstrate histochemically the presence of p65 at rat neuromuscular junctions identified with $\alpha$-bungarotoxin (Fig. 4). As synapsin I had been detected previously at the neuromuscular junction (DeCamilli et al., 1983a), we now had two monospecific antibodies as probes for synaptic vesicle components in cholinergic neurons.

Presence of nerve terminal proteins in early embryos. To examine the appearance of synapsin I and p65 in neurons from early embryos, we determined when in development they first become detectable on protein blots of chick brain membranes. The results in Figure 5 show that p65 can be detected in chick brain as early as embryonic day 5 (E5), and that the level of p65 increases fairly steadily until E18. Control experiments showed that p65 could not be detected in embryonic heart (data not shown). Attempts to demonstrate p65 in embryos younger than E5 were equivocal, due primarily to the difficulty of isolating sufficient protein from the brain at this time. In contrast to these results, synapsin I could not be detected in brain until $E 13$, and its expression increased dramatically between $E 13$ and E16 (Fig. 5). These results indicate that the two proteins are not subject to coordinate regulation.

Expression of vesicle antigens in "mature" nerve-muscle cocultures. When dissociated ciliary ganglion neurons are cultured for 5 to 8 days with chick myotubes, expression of these vesicle antigens can readily be detected immunocytochemically. Indirect immunofluorescence shows that reactivity both for p65 and for synapsin I is present throughout the neurons under these conditions. Staining is not uniform for either antigen, with bright patches separated by lightly stained areas for both cell bodies and neurites. Neurites tend to be more brightly stained, and the brighest staining tends to be where the neurites make contact with a muscle fiber (Fig. 6, $A$ and $C$ ). Muscle fibers themselves are not stained above background, nor are the fibroblast- and glia-like cells which occur sparsely in these cultures.

It seemed likely that the increased levels of fluorescence seen with the antibodies at sites of nerve-muscle contacts reflected neuromuscular synapses. If so, one would expect clusters of AChRs to be present at these patches. Labeling of receptors with rhodamine-conjugated $\alpha$-bungarotoxin revealed that a high percentage of vesicle antigen clusters were associated with patches of AChRs (Fig. 6, $B$ and $D$ ). Quantitation of the data for co-cultures $\geq 5$ days old, summarized in Table I, demonstrates that approximately $80 \%$ of the nerve-muscle contacts showing increased antibody staining were associated with patches of AChRs. This fraction was the same for co-cultures at days 5,7 , or 8 considered alone. The same percentages were obtained whether antibodies to 065 or synapsin I were used to detect vesicle antigens (not shown). In most cases 
Figure 3. Lanes $A$ and $B$ are from a silver-stained SDS gel of purified protein p65. Lane A, $2.4 \mu \mathrm{g}$ of purified p65; lane $B$, molecular weight standard. The arrow points to protein p65, and the arrowhead points to a $40-k d$ band which is bound by a monoclonal antibody to p65. Numbers to the right of $B$ indicate molecular weights $\left(\times 10^{3}\right)$. Some protein from the standard lane runs across lane $A$. Lane $\mathrm{C}$, Coomassie blue stain of $140 \mu \mathrm{g}$ of chick P2. Lanes $D$ and $E$, Protein blot of the same gel, stained with a 1:1000 dilution of antip65 atiserum $(D)$ or preimmune serum $(E)$. Lane $F$, Protein blot of another gel, loaded with $120 \mu \mathrm{g}$ of chick P2 and stained with affinity-purified anti-p65 $(0.25 \mu \mathrm{g} / \mathrm{ml})$. Arrowheads indicate the position of the 68 kd standard.
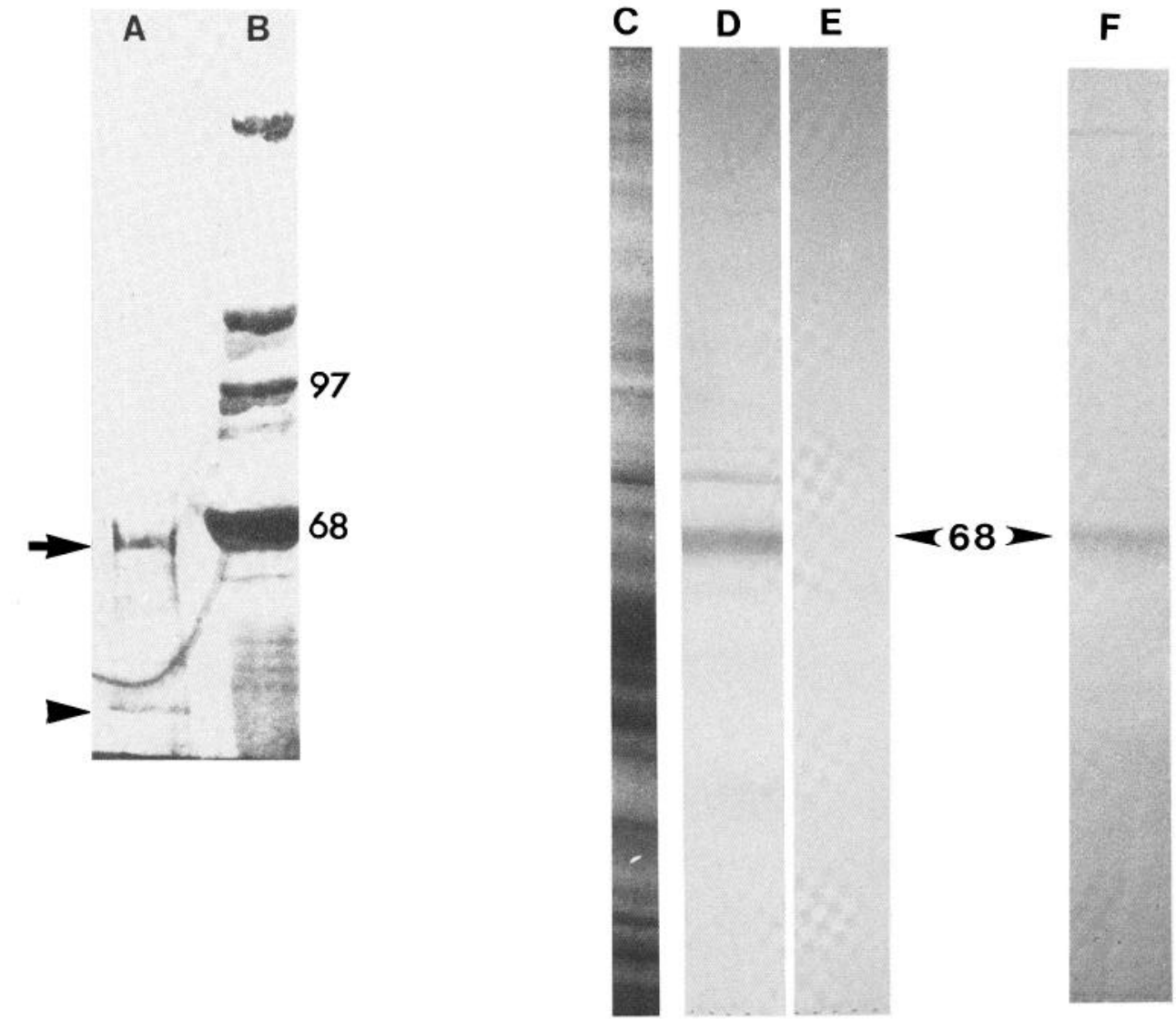

( $94 \%$ ), the patches of bright staining for synaptic antigens either corresponded exactly with or completely covered patches of receptors. However, in some cases, the receptor patches on the muscle were interspersed with the clusters of presynaptic antigen. The frequency of the latter cases did not change systematically with time in culture.

The presence of vesicle antigen clusters and $A C h R$ patches at sites of nerve-muscle contact was investigated systematically, and the data are presented in Table II. The results show that, in mature cultures, $33 \%$ of the neurites that contact myotubes exhibit clusters of p65 antigen (average of days 5 and 8 ). Of these contacts, 75\% were associated with patches of AChRs. In contrast, of the contacts which were not associated with clusters of p65 antigen, only $7 \%$ were associated with receptor patches. Therefore, there is a strong association between patches of receptor and vesicle antigen clusters. These data suggest that p65 and synapsin I are selectively concentrated at synapses in "mature" cultures.

The co-distribution of both protein p65 and synapsin I with receptor patches implies that the two synaptic vesicle antigens are colocalized in these conditions. In some experiments, cultures were stained for both p65 and synapsin I to see whether the apparent coincidence in distribution could be confirmed directly. Figure 7 shows that patches of bright staining for p65 are indeed coincident with those for synapsin I, within our limits of resolution.

Development of expression of nerve terminal antigens in culture. The development of morphological specializations at neuromuscular synapses in vitro (including synaptic vesicle clustering) proceeds over a time course of days (James and Tresman, 1969; Nakajima et al., 1980). To chart the development of vesicle antigen expression in culture, nerve-muscle co-cultures were fixed and examined at various times after plating. The synaptic antigens could be seen as early as 1 day, with a pattern of staining generally like that of older cultures. However, nerve-muscle contacts were immature, with respect to both clustering of receptors and staining for the presynaptic antigens. Of 72 contacts examined, only $11 \%$ exhibited an increased level of staining for p65, and a similar percentage was associated with patches of AChRs. In addition, only $36 \%$ of the contacts showing bright vesicle antigen staining were associated with a receptor patch (Table II). In contrast to the situation at later times, the brightest staining for the synaptic antigens at 1 day was in growth cones and other flattenings and varicosities of the neurites (Fig. 8). Most growth cones were stained, although some appeared to show little staining compared to other areas of the neurite.

As expected, co-cultures examined at intermediate times showed intermediate stages in the localization of pre- and postsynaptic antigens. Both the percentage of nerve-muscle contacts that exhibit increased levels of nerve terminal antigens and the fraction of these "bright" contacts that are associated with a receptor patch increase monotonically during the first 5 days in vitro. In cultures examined at 3 days, $24 \%$ of nerve-muscle contacts showed an increased level of p65 staining, and 45 to $50 \%$ of these were associated with an AChR patch (Tables I and II). Receptor patches were found at $16 \%$ of contacts examined (Table II). At 4 days, examination of only those contacts with increased levels of presynaptic antigens showed that $50 \%$ were at sites containing receptor patches (Table I). Nervemuscle contacts which have a receptor patch but lack a cluster of vesicle antigen constitute a small percentage of contacts at all ages examined (Table II). The percentage of contacts with vesicle antigen clusters but not receptor patches also does not change systematically with time in culture. This is presumably because the fraction of total contacts which have antigen clusters is increasing, whereas the fraction of these antigen-positive contacts without receptor is decreasing.

More data were taken for neurons stained for p65 than for those stained for synapsin I, because staining was generally brighter for p65. However, no differences were detected, either qualitatively (general distribution of fluorescent staining) or quantitatively (percentage of brightly fluorescent contacts associated with receptor 

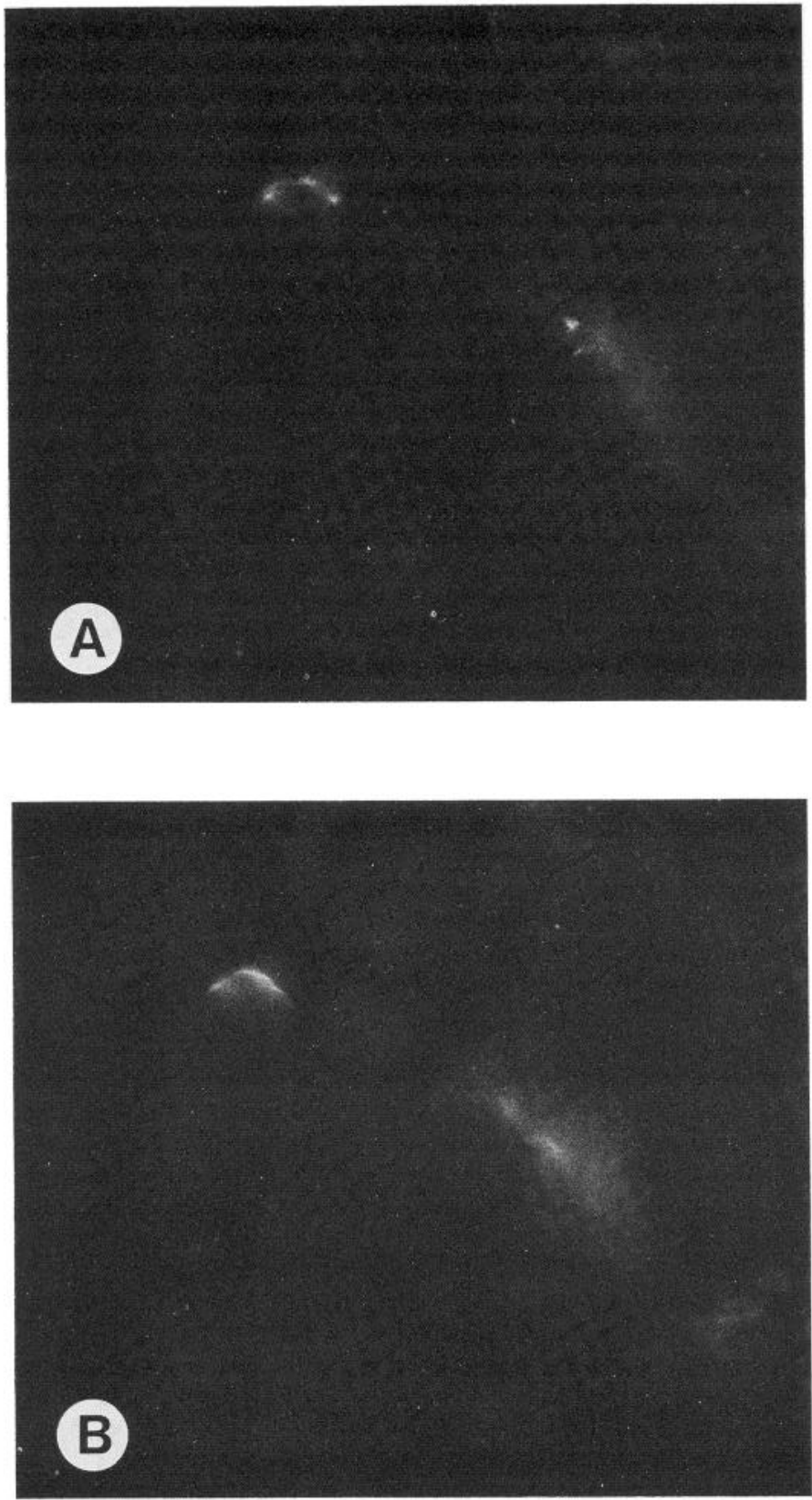

Figure 4. Localization of protein p65 at neuromuscular junctions in vivo. A, Frozen section of rat soleus muscle stained with affinity-purified anti-p65 and fluorescein-conjugated second antibody, photographed with fluorescein optics. Three bright dots of staining are visible at left, and another area of staining, on a second muscle fiber, is out of focus at right. $B$, The same section photographed with rhodamine optics to show the distribution of rhodamine-conjugated $\alpha$-bungarotoxin, which labels AChRs. The same two areas of staining are visible. The line of staining that is in focus covers the area under the fluorescein staining.

patches), between $\mathrm{p} 65$ and synapsin I at any of the ages examined.

Calculations using the data in Table II show that, at all ages examined, those neuronal processes with a cluster of vesicle antigen are much more likely to be associated with a patch of AChRs than neuronal processes lacking a vesicle antigen cluster. Even in the youngest cultures, receptor patches were found 5 -fold more frequently with the former than with the latter (Table II).

Expression of vesicle antigens in neurons cultured alone. Neurons need not be in contact with muscle to express the synaptic vesicle antigens in vitro. As seen in Figure 8 , neurons grown on laminin substrata in the absence of muscle can be stained for both synapsin $I$ and p65. Staining is pronounced in neurites and growth cones. Consistent staining ( 2 of 2 platings) was found only in cultures 5 days old or older, however, even though 1 day of co-culture with muscle was sufficient to attain a similar level of staining (Fig. 8). This is true despite the fact that the neurons were grown in a rich medium (with eye extract) on an optimal substrate (laminin; see Varon et al., 1979; Lander et al., 1985).

\section{Discussion}

Perhaps the most important aspect of the present results is that they provide an immunohistochemical assay, based on known proteins, for synaptogenesis in vitro. This assay should enable us to examine the role of various known molecules (e.g., N-CAM, laminin) in the induction of synaptic differentiation that occurs in co-cultures. It should also be possible to find some of the molecules responsible for the induction and redistribution of the vesicle antigens, using neurons grown in the absence of their target muscle as an assay system.

Purification of vesicle antigens and characterization of specific antisera. The results presented here depend on antisera which specifically recognize synaptic vesicle antigens in chick neurons and are sensitive enough to detect these antigens at developing neuromuscular junctions. The monoclonal antibodies to protein p65 recognize this protein as efficiently in avian as in mammalian species (Matthew et al., 1981), but they were not sensitive enough to detect the p65 protein reliably in neuromuscular junctions $(\mathrm{L}$. Tsavaler and L. F. Reichardt, unpublished observations). We therefore used the p65 protein purified with the monoclonal antibody to develop a polyclonal antiserum of greater sensitivity. Although the p65 protein can be solubilized by several non-ionic detergents, these can also prevent subsequent binding by the monoclonal antibodies (Matthew et al., 1981; J. L. Bixby, unpublished observations). The key to the purification was to identify a detergent, CHAPS, which would solubilize the protein without destroying or masking its antigenicity, so that it could be purified by affinity chromatography. An anti-p65 serum that bound to a $65-k d$ antigen in chick brain, the same antigen as recognized by the monoclonal antibodies (Matthew et al., 1981), was then prepared and used to detect the p65 protein reliably as the neuromuscular junction in vivo. The identification of the protein at the neuromuscular junction increases the probability that the protein has a general role in synaptic vesicle function. The availability of a purified preparation and a polyclonal antiserum should facilitate studies on the function, structure, and genetic regulation of the p65 protein

Polyclonal antibodies to mammalian synapsin I have been used to identify antigens in avian brain and in mammalian neuromuscular junctions, but detection of synapsin I in neuromuscular junctions was difficult (DeCamilli et al., 1983a). To obtain an antibody of higher sensitivity that would be useful for studying avian neuromuscular junctions, it was necessary to purify chick synapsin I, characterize it, and prepare a specific antiserum. Avian synapsin I was purified by a procedure that was essentially identical to that used for the mammalian homologue (Ueda and Greengard, 1977). The purification yielded a doublet with $M_{r}=69,000$ and 76,000 . This doublet appears to be chick synapsin I, but it seems to have been degraded, because antibodies to the doublet bind to a larger doublet of $M_{\mathrm{r}}=$ 78,000 and 79,000 in chick brain membranes, which is also a substrate for CAMP-dependent protein kinase.

These results suggest that synapsin I in chickens is a slightly smaller molecule than its homologue in mammalian brain. The chicken protein shares with mammalian synapsin I the following properties. It is a doublet of apparent $M_{\mathrm{r}}=\sim 80,000$, it is membrane associated but acid extractable, it is present in large amounts in brain, and it is phosphorylated by cAMP-dependent protein kinase. In addition, the antibodies made against the chicken molecule recognize only synapsin I in mammalian brain, and a monoclonal antibody raised against bovine synapsin I recognizes only the dou- 
Figure 5. Protein blots of chick brain membranes (P2) from chick embryos at different stages of development. Lanes on the left were stained with affinity-purified anti-chick synapsin I $(0.6 \mu \mathrm{g} / \mathrm{ml})$, and lanes on the right were stained with affinity-purified anti-p65 $(0.5 \mu \mathrm{g} / \mathrm{ml})$. Each lane was loaded with $200 \mu \mathrm{g}$ of protein. Arrowheads and numbers indicate calculated molelcular weights $\left(\times 10^{3}\right)$. Ages of chicks from which brains were taken are indicated at the top. The $79 \mathrm{kd}$ band in $D$ is barely visible but is present. A band near the top of the gel is stained nonspecifically by the second antibody. $P O=$ day of hatching.

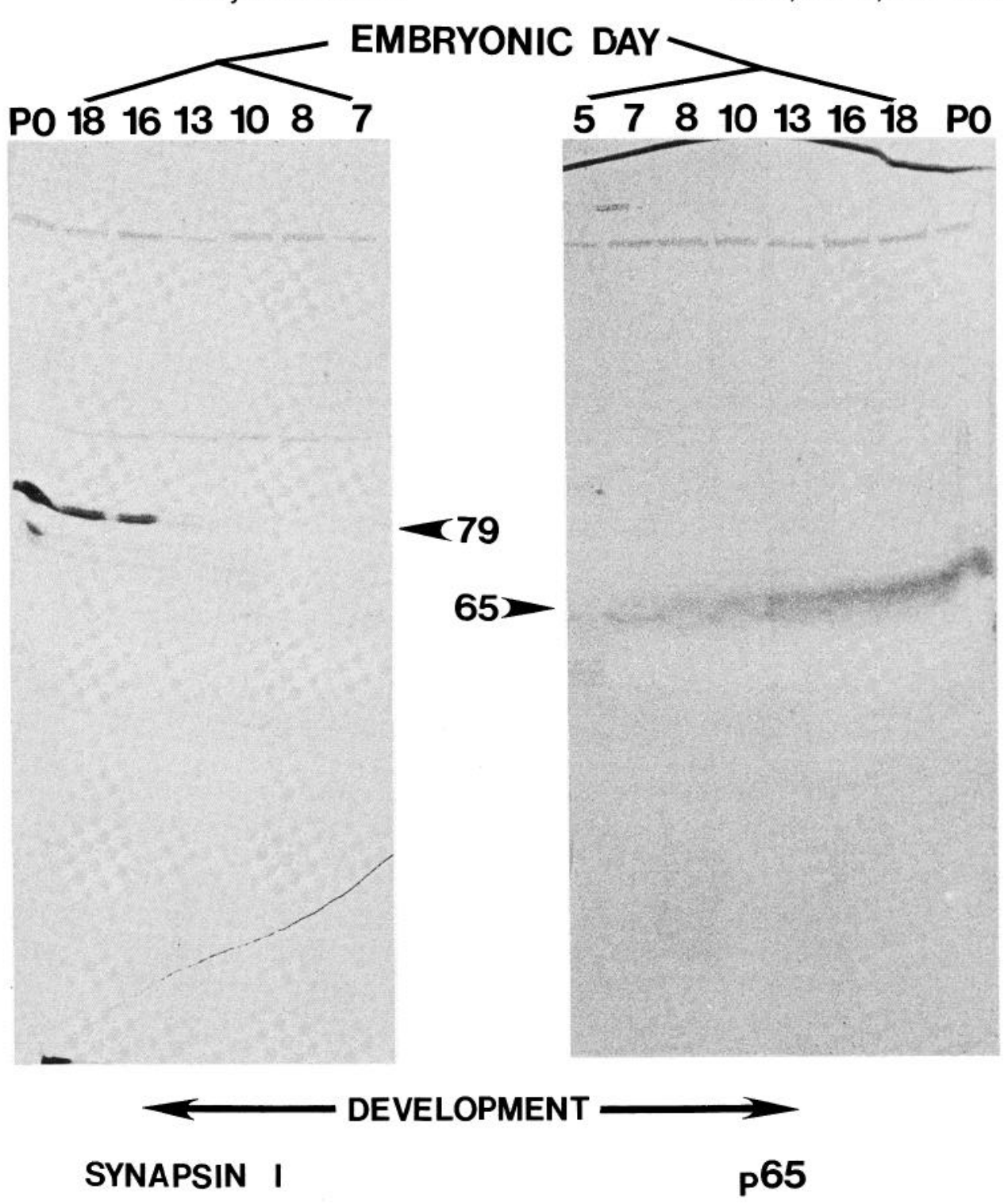

blet in chicken brain. Finally, the purified antibody raised against the chicken molecule binds to an antigen which co-localizes with p65, a known synaptic vesicle antigen, in nerve-muscle co-cultures. Thus, the evidence indicates that chicken brain contains a molecule homologous to synapsin I, which is a doublet of apparent $M_{r}=$ 78,000 and 79,000 .

Appearance of vesicle antigens in vivo. The polyclonal antisera to $\mathrm{p} 65$ and synapsin I have made it possible to detect these antigens in early embryonic brain. Protein blots show that p65 is present in embryonic chick brain at very early times, and its expression gradually increases during embryonic development. Synapsin I, in contrast, was not detected until later (E13), and its expression increased sharply between $\mathrm{E} 13$ and $\mathrm{E} 16$. Since these proteins are associated with synaptic terminals in mature brain, one might expect a correlation between the onset of rapid synapse formation and an increase in 065 and synapsin I expression. In agreement with this expectation, there is evidence that the appearance of synapsin I is closely correlated with synapse formation in the cerebellum (DeCamilli et al., 1983a; Levitt et al., 1984). It is difficult to assign a single period of rapid synapse formation to the entire chick brain, since areas develop asynchronously. However, a broad period of synapse formation between $\mathrm{E} 10$ and $\mathrm{E} 16$ is consistent with the results obtained for the cerebellum and the optic tectum (LaVail and Cowan, 1971;
Foelix and Oppenheim, 1974), which would correlate reasonably well with synapsin I expression. In contrast, it seems unlikey that there are significant numbers of synapses in chick brain at the earliest times when p65 was detected. The results suggest, therefore, that initial synthesis of p65, and perhaps of synaptic vesicles, will not prove to be tightly correlated with synapse formation. Whether the difference between regulation of $\mathrm{p} 65$, an integral vesicle protein, and synapsin I, a peripherially associated vesicle protein, reflects a functional distinction is not known. The p65 protein has been detected in neurosecretory cells, such as adrenal chromaffin cells, whereas synapsin I has been reported only in neurons that make synaptic contacts (Bloom et al., 1979; Matthew et al., 1981).

Appearance of vesicle proteins in vitro. Both p65 and synapsin I are expressed in ciliary ganglion cells in vitro. In the culture system, synapsin I can be detected in axons and somata prior to the time when most synapses form. This is in apparent contrast to the situation in vivo, where synapsin I expression seems to be correlated with synapse formation. Whether this is a real difference cannot be determined without a more detailed examination of the time course of expression in vivo. By 4 to 5 days in culture, both synaptic antigens become concentrated at appropriate locations, opposite patches of AChRs. This suggests strongly that nerve and muscle interact in vitro to produce localization of their respective synaptic 

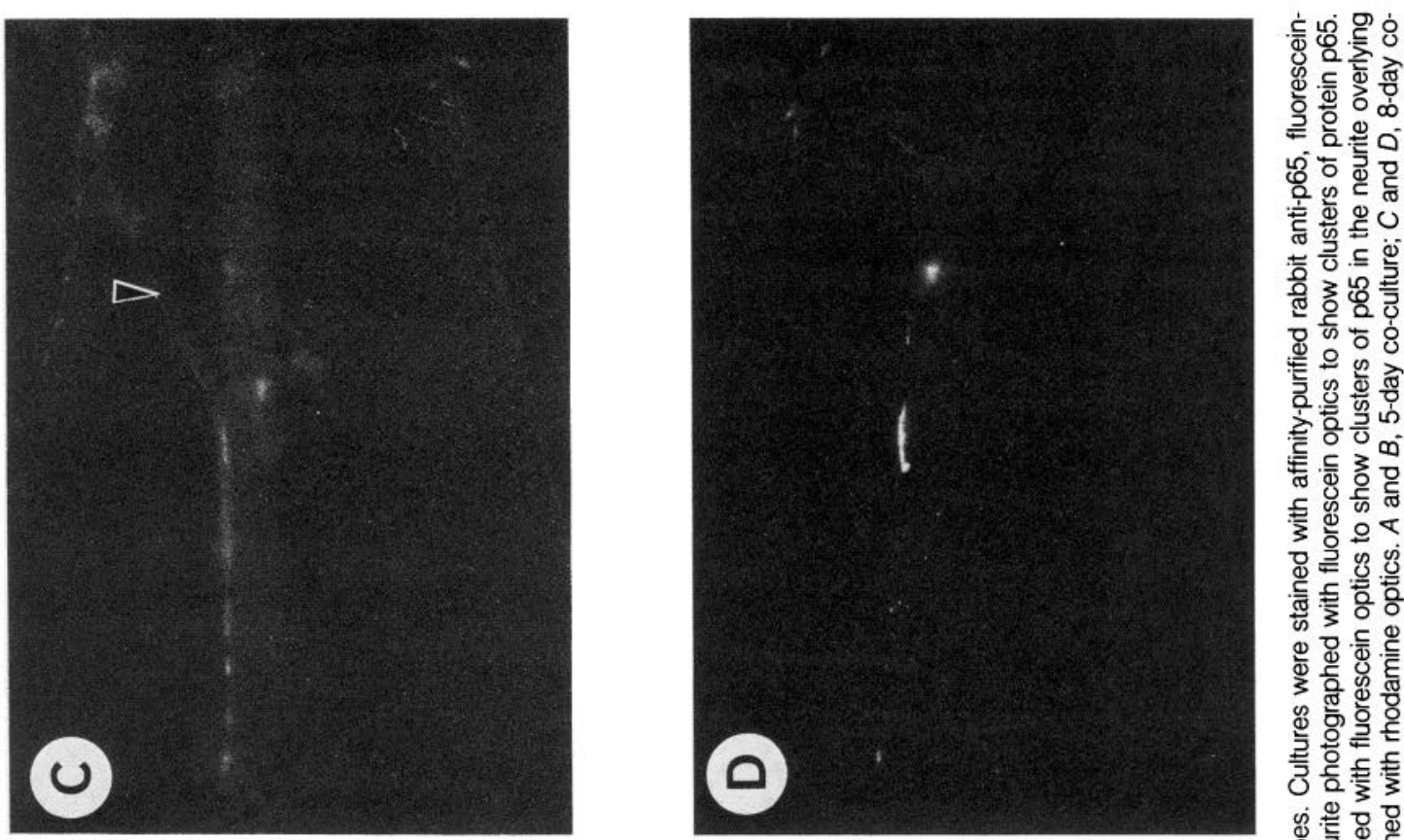

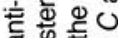

政 $\subseteq$

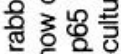

的酧

은

की की

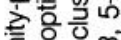

更

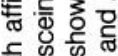

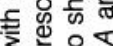

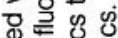

骞

a 0

要

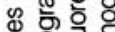

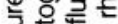

공응 专

讨

를 응 융

훈 항

등
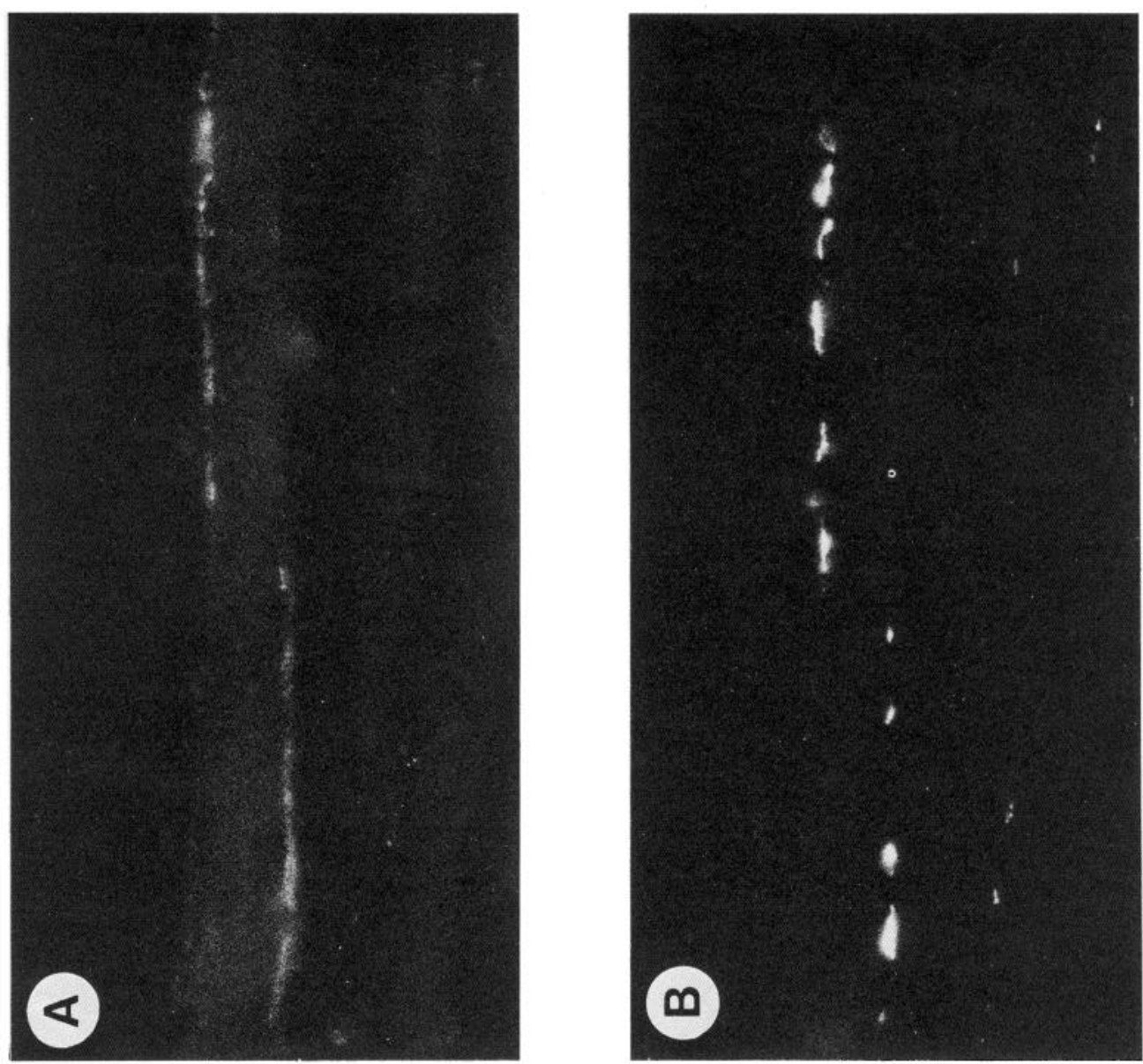

당ㅎㅀ응응

os

के है

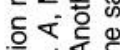

कप

可以

>잉

恶

Ū

훙형

항ㅇㅇ

表

을

oे

더

क

등 응

은 흥

믇능 중

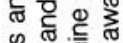

츄요

응 흉

들 을

는

कृ

ब 0

엉

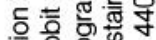

今

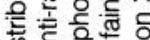

. 등

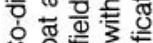

0 o

0 응

त क

के

近容在 
components. Whether the induction of synaptic antigens occurs in neurons as a consequence of the presence of their target tissue is unknown. Preliminary experiments in this paper suggest that the vesicle antigens are expressed in cultures of dissociated neurons without muscle, but that their expression is increased upon coculture with muscle. This problem can best be approached with a quantitative assay for the proteins.

The 5-day culture period necessary for "mature" localization of vesicle antigens is consistent with the time found in other studies to

TABLE I

Association between antigen clusters and receptor patches

\begin{tabular}{cc}
\hline $\begin{array}{c}\text { Days in } \\
\text { Culture }\end{array}$ & $\begin{array}{c}\text { Contacts with Vesicle } \\
\text { Antigen Cluster } \\
\text { Having }\end{array}$ \\
$\begin{array}{c}\text { AChR Patch } \\
(\%)\end{array}$ \\
\hline $1(N=10)$ & 20 \\
$3(N=40)$ & 45 \\
$4(N=34)$ & 50 \\
$5(N=37)$ & 84 \\
$7(N=17)$ & 76 \\
$8(N=61)$ & 84
\end{tabular}

${ }^{a}$ Data for p65 and synapsin I taken together. be required for morphological specialization of neuromuscular contacts in vitro. Rat spinal cord explants take 4 to 6 days in culture to accumulate synaptic vesicles in terminals on muscle (Nakajima et al., 1980). Similarly, 2 to 4 days are required before clusters of synaptic vesicles can be identified at neuromuscular junctions formed in vitro by chick spinal cord (James and Tresman, 1969). This correlation lends support to the notion that the clusters of vesicle antigen staining reflect synaptic differentiation.

The co-localization of two rather different vesicle-specific antigens in the nerve-muscle co-cultures suggest that the fluorescence assay reveals clusters of synaptic vesicles. The appearance of these clusters at sites of neuromuscular contact in conjunction with patches of AChRs is thus likely to be a good measure of synaptic maturation. This suggestion is supported by the finding of Betz (1976), that in mature ciliary ganglion-myotube co-cultures, approximately $30 \%$ of nerve-muscle contacts resulted in functional synapses, in good agreement with the fraction of contacts found in our experiments to have clusters of vesicle antigens and patches of AChRs. The small fraction of contacts found in "mature" cultures to possess receptor patches but not vesicle antigen clusters could reflect an early stage of presynaptic differentiation or an inadequacy in the qualitative criterion of increased fluorescent staining for the vesicle antigens.

TABLE ॥

Percentage of nerve-muscle contacts exhibiting vesicle antigen and receptor clusters

\begin{tabular}{|c|c|c|c|c|c|c|c|c|}
\hline $\begin{array}{l}\text { Days in } \\
\text { Culture }\end{array}$ & $\begin{array}{l}\text { No p65 Cluster, } \\
\text { No AchR Patch }\end{array}$ & $\begin{array}{l}\text { No p65 Cluster, } \\
\text { AChR Patch }\end{array}$ & $\begin{array}{l}\text { p65 Cluster, } \\
\text { AChR Patch }\end{array}$ & $\begin{array}{l}\text { p65 Cluster, No } \\
\text { AChR Patch }\end{array}$ & $\begin{array}{l}\text { Total } \\
\text { p65 }\end{array}$ & Total AChR & $\begin{array}{l}\text { p65 with } \\
\text { AChR }\end{array}$ & $\begin{array}{c}\text { p65- with } \\
\text { AChR }\end{array}$ \\
\hline $1(N=72)$ & 82 & 7 & 4 & 7 & 11 & 11 & 36 & 7.9 \\
\hline $3(N=76)$ & 72 & 4 & 12 & 12 & 24 & 16 & 50 & 5.3 \\
\hline $8(N=62)$ & 55 & 11 & 26 & 8 & 34 & 37 & 76 & 16.7 \\
\hline
\end{tabular}
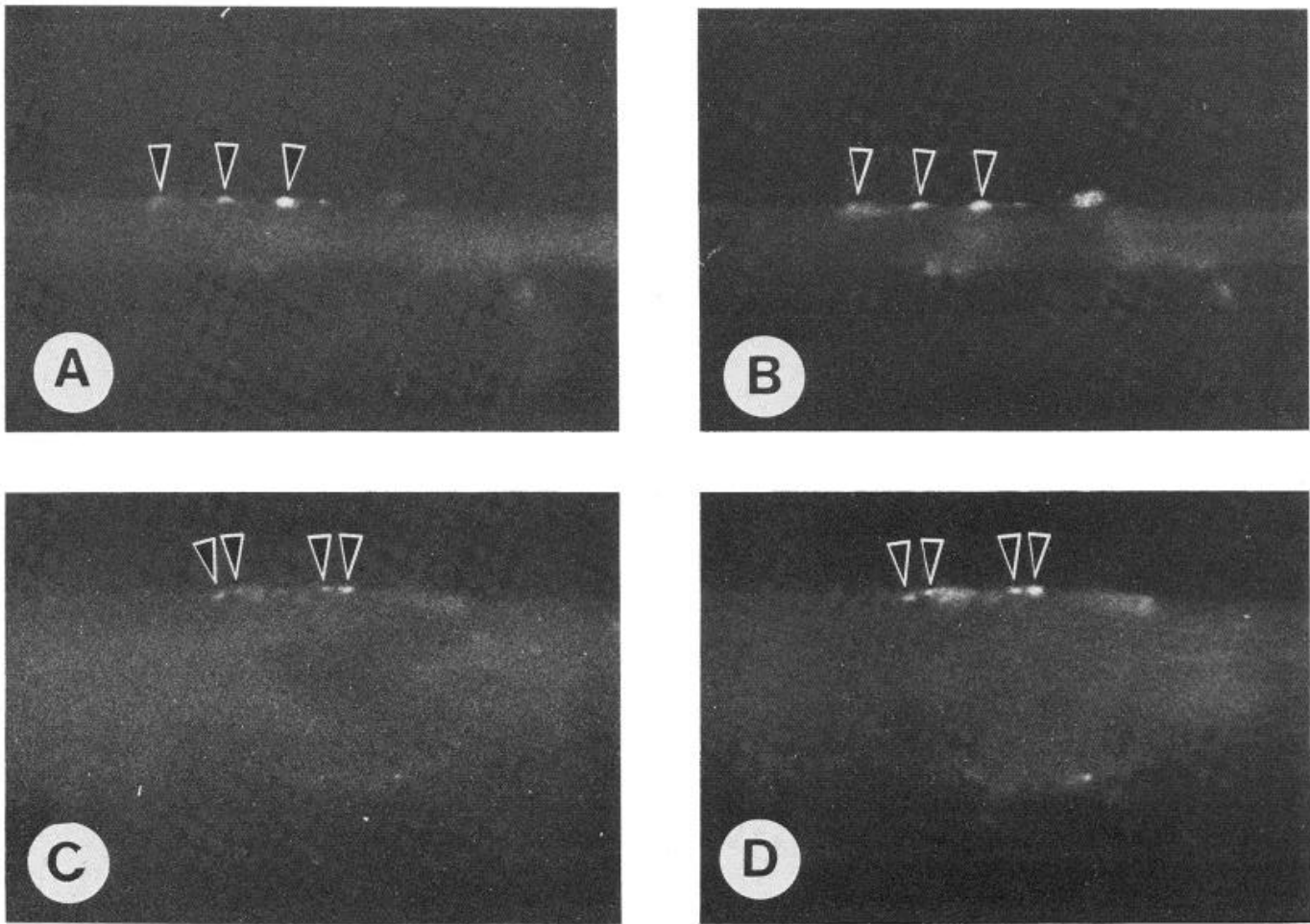

Figure 7. Exact co-localization of protein p65 and synapsin I in nerve-muscle co-cultures. Cultures were stained with affinity-purified rabbit anti-chick synapsin I, a mouse monoclonal antibody to protein p65, fluorescein-conjugated goat anti-rabbit second antibody, and rhodamine-conjugted goat antimouse second antibody. $A$, Clusters of synapsin I staining revealed with flourescein optics (arrowheads). $B$, The same field photographed with rhodamine optics to reveal p65 staining. The same clusters are seen. The patch of staining not arrowed is a piece of debris, which shows up more strongly in the rhodamine picture $C$, Clusters of synapsin I staining on a second myotube, photographed with fluorescein optics (arrowheads). $D$, The same field photographed with rhodamine optics. All are 5-day co-cultures. Magnification $\times 5600$. 

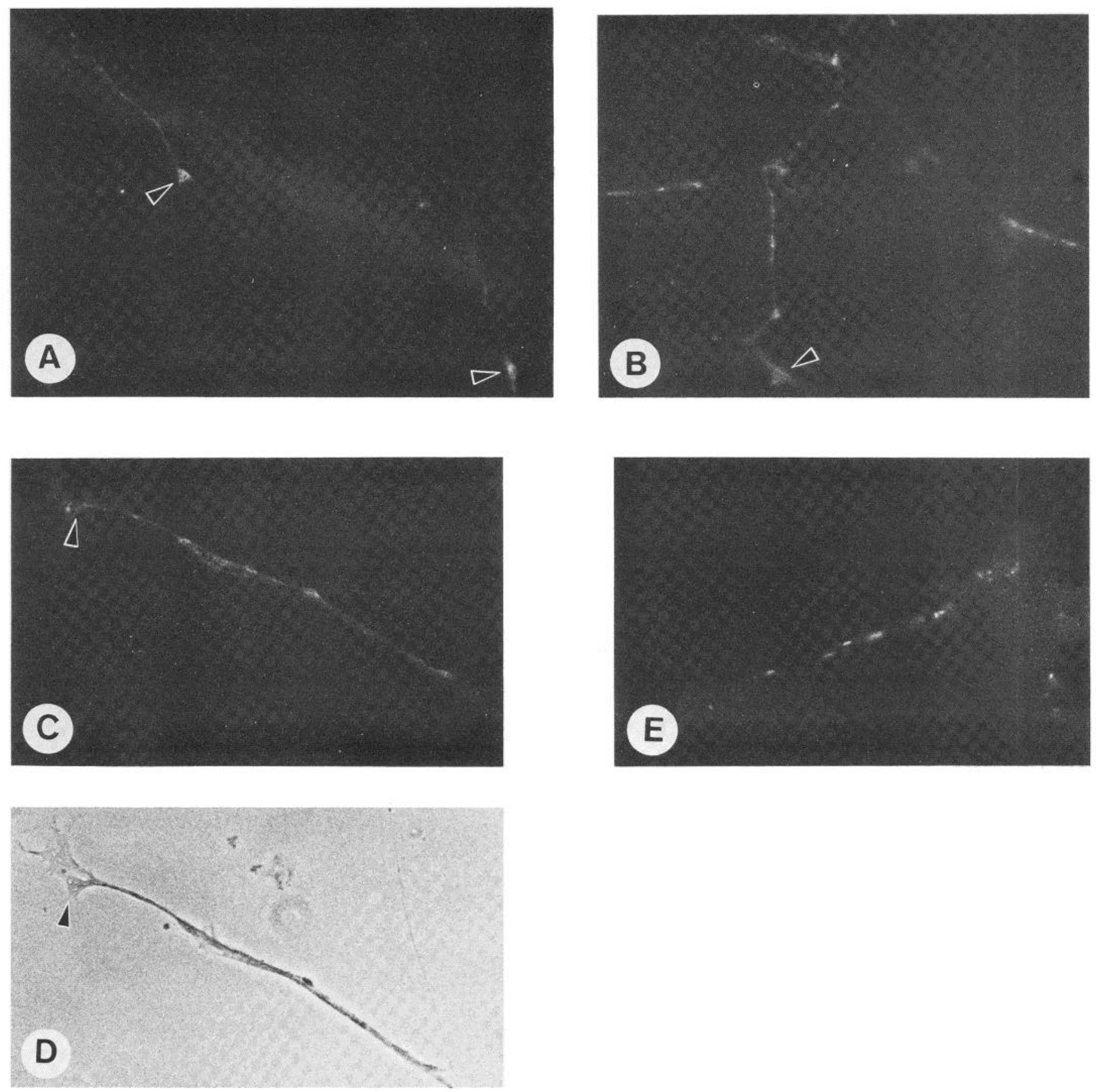

Figure 8. Staining of vesicle antigens in neurites and growth cones. A, Two neurites with brightly staining growth cones (arrowheads) course over a muscle fiber. Anti-p65, 1-day nerve-muscle co-culture. B, Neurites and growth cones (arrowhead) exhibit patchy staining. Anti-p65, 1-day nerve-muscle coculture. $C, A$ neurite and its growth cone (arrowhead) are stained. Anti-p65, 5-day culture of neurons alone. $D$, The same field photographed with phase contrast optics. $E, A$ neurite and cell body exhibit patchy staining. Anti-synapsin I, 5-day culture of neurons alone. Magnifications: $A$ and $B, \times 3300 ; C$ and $D, \times 4500$.

It is unlikely that the apppearance of clusters of vesicle antigens is a reflection of the initiation of functional synaptic transmission per se. Ciliary ganglion neurons are capable of releasing acetylcholine from growth cones (Hume et al., 1983), and the time required for establishment of neuromuscular transmission in vitro seems to be limited only by the rate of neurite outgrowth (e.g., Cohen, 1980). Although the vesicle antigens can be seen in growth cones, it takes several days for "mature" contacts to appear with appreciable frequency. Our assay is a measure of synaptic maturation rather than formation.
Note added in proof: Two recent studies have identified proteins related to synapsin I in chick brain (Sorensen, R. G., and J. A. Babitch (1984) J. Neurochem. 42: 705-710; Goelz, S. E., E. J. Nestler, and P. Greengard (1985) J. Neurochem. 45: 63-72.).

\section{References}

Betz, W. (1976) Functional and non-functional contacts between ciliary neurones and muscle grown in vitro. J. Physiol. (Lond.) 254: 75-86.

Bloch, R. J., and Z. W. Hall (1983) Cytoskeletal components of the vertebrate 
neuromuscular junction: Vinculin, a-actinin, and filamin. J. Cell Biol. 97: $217-223$

Bloom, F. E., T. Ueda, E. Battenberg, and P. Greengard (1979) Immunohistochernical localization, in synapses, of protein I, an endogenous substrate for protein kinases in mammalian brain. Proc. Natl. Acad. Sci. U. S. A. 76 : 5982-5986.

Bruck, C., D. Portelle, C. Glineur, and A. Bollen (1982) One-step purification of mouse monoclonal antibodies from ascitic fluid by DEAE Affi-Gel Blue chromotography. J. Immunol. Methods 53: 313-319.

Buckley, K., and R. B. Kelly (1985) Identification of a transmembrane glycoprotein specific for secretory vesicles of neural and endocrine cells. J. Cell Biol. 100: 1281-1294.

Burden, S. (1982) Identification of an intracellular postsynaptic antigen at the frog neuromuscular junction. J. Cell Biol. 94: 521-530.

Burden, S. J., R. L. DePalın, and G. S. Gottesman (1983) Crossliriking of proteins in acetylcholine receptor-rich membranes: Association between the B-subunit and the 43-kd protein. Cell 35: 687-692.

Calof, A. L., and L. F. Reichardt (1984) Motoneurons purified by cell sorting respond to two distinct activities in myotube conditioned medium. Dev. Biol. 106: 194-210.

Carlson, S. S., and R. B. Kelly (1983) A highly antigenic proteoglycan-like component of cholinergic synaptic vesicles. J. Biol. Chem. 258: 1108211091.

Cohen, S. A. (1980) Early nerve-muscle synapses in vitro release transmitter over postsynaptic membrane having low acetylcholine sensitivity. Proc Natl. Acad. Sci. U. S. A. 77: 644-648.

Cohen, S. S., and G. D. Fischbach (1977) Clusters of acetylcholine receptors located at identified nerve-muscle synapses in vitro. Dev. Biol. 59: 24-38.

DeCamilli, P., R. Cameron, and P. Greengard (1983a) Synapsin I (protein I), a nerve terminal-specific phosphoprotein. I. Its general distribution in synapses of the central and peripheral nervous system demonstrated by immunoflourescence in frozen and plastic sections. J. Cell Biol. 96: 13371354.

DeCamilli, P., S. M. Harris, W. B. Huttner, and P. Greengard (1983b) Synapsin I (protein I), a nerve terminal-specific phosphoprotein. II. Its specific association with synaptic vesicles demonstrated by immunocytochemistry in agarose-embedded synaptosomes. J. Cell Biol. 96: 1355-1373.

Engvall, E. (1980) Enzyme immunoassay ELISA and EMIT. Methods Enzymol. 70: 419-439.

Fambrough, D. M. (1979) Control of acetylcholine receptors in skeletal muscle. Physiol. Rev. 59: 165-227.

Foelix, R. F., and R. Oppenheim (1974) The development of synapses in the cerebellar cortex of the chick embryo. J. Neurocytol. 3: 277-294.

Forn,J., and P. Greengard (1978) Depolarizing agents and cyclic nucleotides regulate the state of phosphorylation of specific neuronal proteins in rat cerebral cortex slices. Proc. Natl. Acad. Sci. U. S. A. 75: 5195-5199.

Greif, K., and L. F. Reichardt (1982) Appearance and distribution of neuronal cell surface and synaptic vesicle antigens in the developing rat superior cervical ganglion. J. Neurosci. 2: 843-852.

Hall, Z. W., B. W. Lubit, and J. H. Schwartz (1981) Cytoplasmic actin in postsynaptic structures at the neuromuscular junction. J. Cell Biol. 90: 789-792.

Hawkes, R., E. Niday, and J. Gordon (1982) A dot-immunobinding assay for monoclonal and other antibodies. Anal. Biochem. 119: 142-147.

Hume, R. I., L. W. Role, and G. D. Fischbach (1983) Acetylcholine release from growth cones detected with patches of acetylcholine receptor-rich membranes. Nature 305: 632-634.

Huttner, W. B., and P. Greengard (1979) Multiple phosphorylation sites in protein I and their differential regulation by cyclic AMP and calcium. Proc. Natl. Acad. Sci. U. S. A. 76: 5402-5406.

Huttner, W. B., W. Schiebler, P. Greengard and P. DeCamilli (1983) Synapsin I (proteın I), a nerve terminal-specific phosphoprotein. III. Its association with synaptic vesicles studied in a highly purified synaptic vesicle preparation. J. Cell Biol. 96: 1374-1388.

James, D. W., and R. L. Tresman (1969) An electron-microscopic study of the de novo formation of neuromuscular junctions in tissue culture. $Z$ Zellforsch. 100: 126-140.

Kleinman, H. K., M. L. McGarvey, L. A. Liotta, P. G. Robey, K. Tryggvason, and G. R. Martin (1982) Isolation and characterization of type IV procollagen, laminin, and heparan sulfate proteoglycan from the EHS sarcoma Biochemistry 21: 6188-6193.

Laemmli, U. K. (1970) Cleavage of structural proteins during the assembly of the head of bacteriophage T4. Nature 227: 680-685.

Lander, A. D., D. K. Fujii, and L. F. Reichardt (1985) Laminin is associated with the "neurite outgrowth-promoting factors" found in conditioned media. Proc. Natl. Acad. Sci. U. S. A. 82: 2183-2187

Landmesser, L., and G. Pilar (1971) Synaptic transmission and cell death during normal ganglionic development. J. Physiol. (Lond.) 241: 737-749.

LaVail, J. H., and W. M. Cowan (1971) The development of chick optic teclum. I. Normal morphology and cytoarchitectonic development. Brain Res. 28: 391-419.

Levitt, P., P. Rakic, P. DeCamilli, and P. Greengard (1984) Emergence of cyclic guanosine $3^{\prime}: 5^{\prime}$-monophosphate-dependent protein kinase immunoreactivity in developing rhesus monkey cerebellum: Correlative immunocytochemical and electron microscopic analysis. J. Neurosci. 4: 25532564

Lohmann, S. M., T. Ueda, and P. Greengard (1978) Ontogeny of synaptic phosphoproteins in brain. Proc. Natl. Acad. Sci. U. S. A. 75: 4037-4041.

Matthew, W. D., L. Tsaveler, and L. F. Reichardt (1981) Identification of a synaptic vesicle-specific membrane protein with a wide distribution in meuronal and neurosecretory tissue. J. Cell Biol. 91: 257-269.

Nakajima, Y., Y. Kidokoro, and F. G. Klier (1980) The development of functional neuromuscular junctions in vitro: An ultrastructural and physiological study. Dev. Biol. 77: 52-72.

Nishi, R., and D. K. Berg (1977) Dissociated ciliary ganglion neurons in vitro: Survival and synapse formation. Proc. Natl. Acad. Sci. U. S. A. 74: $5171-$ 5175 .

Nishi, R., and D. K. Berg (1981) Two components from eye tissue that differentially stimulate the growth and development of ciliary ganglion neurons in cell culture. J. Neurosci. 1: 505-513.

Ravdin, P. R., and D. Axelrod (1977) Fluorescent tetramethyl rhodamine derivatives of $\alpha$-bungarotoxin: Preparation, separation, and characterization. Anal. Biochem. 80: 585-592.

Schaffner, W., and C. Weissmann (1973) A rapid, sensitive, and specific method for the determination of protein in dilute solution. Anal. Biochem. 56: 502-514

Towbin, H., T. Staehelin, and J. Gordon (1979) Electrophoretic transfer of proteins from polyacrylamide gels to nitrocellulose sheets: Procedure and some applications. Proc. Natl. Acad. Sci. U. S. A. 76: 4350-4354.

Ueda, T., and P. Greengard (1977) Adenosine $3^{\prime}: 5^{\prime}$-monophosphate-regulated phosphoprotein system of neuronal membranes. I. Solubilization, purification, and some properties of an endogenous phosphoprotein. J. Biol. Chem. 252: 5155-5163.

Uno, 1., T. Ueda, and P. Greengard (1977) Adenosine $3^{\prime}: 5^{\prime}$-monophosphateregulated phosphoprotein system of neuronal membranes. Ill. Solubilization, puritication, and some properties of an endogenous $3^{\prime}: 5^{\prime}$-monophosphate-dependent protein kinase. J. Biol. Chem. 252: 5164-5174.

Varon, S., M. Manthorpe, and R. Adler (1979) Cholinergic neuronotrophic factors. I. Survival, neurite outgrowth and choline acetyltransferase activity in monolayer cultures from chick embryo ciliary ganglia. Brain Res. 173: 29-45.

Walaas, S. I., A. C. Nairn, and P. Greengard (1983a) Regional distribution of calcium- and cyclic adenosine $3^{\prime}: 5^{\prime}$-monophosphate-regulated protein phosphorylation systems in mammalian brain. I. Particulate systems. J. Neurosci. 3: 291-301.

Walaas, S. I. A. C. Nairn, and P. Greengard (1983b) Regional distribution of calcium- and cyclic adenosine $3^{\prime}: 5^{\prime}$-monophosphate-regulated protein phosphorylation systems in mammalian brain. II. Soluble systems. J. Neurosci. 3: 302-311. 